\title{
Soil carbon dioxide emissions controlled by an extracellular oxidative metabolism identifiable by its isotope signature
}

\author{
Benoit Kéraval $^{1,2,3}$, Anne Catherine Lehours ${ }^{1,2}$, Jonathan Colombet ${ }^{1,2}$, Christian Amblard ${ }^{1,2}$, Gaël Alvarez ${ }^{3,4}$, and \\ Sébastien Fontaine ${ }^{3}$ \\ ${ }^{1}$ Clermont Université, Université Blaise Pascal, Laboratoire Microorganismes : Génome et Environnement, BP 10448, \\ 63000 Clermont-Ferrand, France \\ ${ }^{2}$ CNRS, UMR 6023, Laboratoire Microorganismes : Génome et Environnement, 63178 Aubière, France \\ ${ }^{3}$ INRA, UR874 (Unité de Recherche sur 1'Ecosystème Prairial), 5 Chemin de Beaulieu, 63039 Clermont-Ferrand, France \\ ${ }^{4}$ Clermont Université, VetAgro Sup, BP 10448, 6300 Clermont-Ferrand, France \\ Correspondence to: Benoit Kéraval (benoit.keraval@gmail.com)
}

Received: 3 August 2015 - Published in Biogeosciences Discuss.: 4 April 2016

Revised: 19 September 2016 - Accepted: 22 September 2016 - Published: 28 November 2016

\begin{abstract}
Soil heterotrophic respiration is a major determinant of the carbon $(\mathrm{C})$ cycle and its interactions with climate. Given the complexity of the respiratory machinery, it is traditionally considered that oxidation of organic $\mathrm{C}$ into carbon dioxide $\left(\mathrm{CO}_{2}\right)$ strictly results from intracellular metabolic processes. Here we show that $\mathrm{C}$ mineralization can operate in soils deprived of all observable cellular forms. Moreover, the process responsible for $\mathrm{CO}_{2}$ emissions in sterilized soils induced a strong $\mathrm{C}$ isotope fractionation (up to $50 \%$ o incompatible with respiration of cellular origin. The supply of ${ }^{13} \mathrm{C}$ glucose in sterilized soil led to the release of ${ }^{13} \mathrm{CO}_{2}$ suggesting the presence of respiratory-like metabolism (glycolysis, decarboxylation reaction, chain of electron transfer) carried out by soil-stabilized enzymes, and by soil mineral and metal catalysts. These findings indicate that $\mathrm{CO}_{2}$ emissions from soils can have two origins: (1) from the well-known respiration of soil heterotrophic microorganisms and (2) from an extracellular oxidative metabolism (EXOMET) or, at least, catabolism. These two metabolisms should be considered separately when studying effects of environmental factors on the $\mathrm{C}$ cycle because the likelihood is that they do not obey the same laws and they respond differently to abiotic factors.
\end{abstract}

\section{Introduction}

Mineralization of soil organic matter (SOM) into $\mathrm{CO}_{2}$ and mineral nutrients is central to the functioning of eco- and agro-systems in sustaining nutrient supply and plant primary production. Soil carbon (C) mineralization is also a major determinant of the global $\mathrm{C}$ cycle and climate by releasing, from land surfaces, an equivalent of 10 times that of anthropogenic $\mathrm{CO}_{2}$ emissions (IPCC, 2007; Paterson and Sim, 2013). Therefore, knowledge of the metabolic pathways by which SOM is oxidized is crucial to predicting both food production and the climate under a changing environment.

Traditionally, it is considered that SOM mineralization results from the activity of soil microbial communities through biologically catalyzed processes including both extracellular depolymerization and cellular metabolisms. Extracellular depolymerization converts high-molecular-weight polymers like cellulose into soluble substrates assimilable by microbial cells. This depolymerization is performed by extracellular enzymes released in soil through microbial cell excretion and lysis (Burns et al., 2013). In cells, assimilated substrates are carried out by a cascade of endoenzymes (Sinsabaugh et al., 2009; Sinsabaugh and Follstad Shah, 2012), along which protons and electrons are transferred from a substrate to intermediate acceptors (e.g. NADP) and small C compounds are decarboxylated into $\mathrm{CO}_{2}$. At the end of the cascade, the final acceptor (e.g. $\mathrm{O}_{2}$ under aerobic conditions) receives the 
protons and electrons while the gradient of $\mathrm{H}^{+}$generated is used by ATP synthase to produce ATP (Junge et al., 1997).

Given the complexity of its machinery it is often believed that respiration is strictly an intracellular metabolic process. However, this paradigm is challenged by recurrent observations of persistent substantial $\mathrm{CO}_{2}$ emissions in soil microcosms where sterilization treatments (e.g. $\gamma$-irradiation) reduced microbial activities to undetectable levels (Blankinship et al., 2014; Kemmitt et al., 2008; Lensi et al., 1991; Maire et al., 2013; Ramsay and Bawden, 1983; Trevors, 1996). Maire et al. (2013) addressed this issue and proposed that extracellular oxidative metabolisms (EXOMET) contribute to soil respiration. According to these authors, intracellular enzymes involved in cell oxidative metabolism are released during cell lysis and retain their activities in soil thanks to the protective role of soil particles. These enzymes are able to oxidize ${ }^{13} \mathrm{C}$ glucose to ${ }^{13} \mathrm{CO}_{2}$ using $\mathrm{O}_{2}$ as the final electron acceptor suggesting that all or part of the cascade of biochemical reactions involved in cell oxidative metabolism are reconstructed outside the cell (Maire et al., 2013). As an alternative explanation, Blankinship et al. (2014) proposed that some decarboxylases, retaining activities outside the cell in sterilized soils, catalyze $\mathrm{CO}_{2}$ emissions through decarboxylation of intermediary metabolites of the Krebs cycle. Whereas differing in the complexity of the proposed mechanisms, these results suggest that (i) $\mathrm{CO}_{2}$ emissions from soils are not only dependent on the bio-physicochemical environment provided by the cells and (ii) indicate that the soil microenvironment heterogeneity offers a range of physicochemical conditions allowing endoenzymes to be functional.

Despite these recent advances, the paradigm that only a cell can organize the complex machinery, achieving the complete oxidation of organic matter at ambient temperature, remains established in the scientific community (see published discussions generated by Maire et al., 2013). In this vein, some authors suggested that $\mathrm{CO}_{2}$ emissions from $\gamma$ irradiated soils can result from "ghost cells" (nonproliferating but morphologically intact cells) which conserve some cellular metabolic activities during prolonged periods of time (Lensi et al., 1991; Ramsay and Bawden, 1983).

The objective of the present study was to determine whether a purely EXOMET can occur in a soil deprived of active and "ghost" cells. To this aim, high doses of $\gamma$ irradiation and different times of soil autoclaving were combined to suppress both biomass and necromass ("ghost" cells). The presence or absence of active and non-active cells in soil was checked by observations with transmission electron microscopy (TEM) on tangential ultrathin sections of soil, DNA and RNA soil content and flow cytometry. The production and the isotope composition $\left(\delta^{13} \mathrm{C}\right)$ of $\mathrm{CO}_{2}$ were monitored in sterilized and non-sterilized soils over four periods through 91 days of incubation. We also tested whether the EXOMET in sterilized soils can carry out a complex cascade of biochemical reactions (e.g. an equivalent of glycol- ysis and the Krebs cycle) by incorporating ${ }^{13} \mathrm{C}$-labeled glucose and by quantifying emissions of ${ }^{13} \mathrm{C}^{-} \mathrm{CO}_{2}$ (Fig. 1).

\section{Material and methods}

\subsection{Soil sampling, sterilization, and incubation}

Samples were collected in November 2012 from a 40-60 cm soil layer at a site in Theix (Massif Central, France). The soil is sandy loam Cambisol developed on granitic rock $\left(\mathrm{pH}=6.5\right.$, carbon content $\left.=23.9 \pm 1 \mathrm{~g} \mathrm{C} \mathrm{kg}^{-1}\right)$. For detailed information on the site see Fontaine et al. (2007). Fresh soil samples were mixed, sieved at $2 \mathrm{~mm}$, dried to $10 \%$, and irradiated with gamma rays at $45 \mathrm{kGy}\left({ }^{60} \mathrm{Co}\right.$, IONISOS, ISO 14001, France). To demonstrate the absence of viable cells in soil after irradiation, we inoculated culture medium for bacteria (LB agar) and fungi (yeast malt agar) with irradiated soil and we applied CARD-FISH to irradiated soil extracts. Results showed the absence of any microbial proliferation and RNA-producing cells (Maire et al., 2013). After irradiation, some sets of soil samples were exposed to autoclaving at $121^{\circ} \mathrm{C}$ during variable periods $(0.5,1,1.5,2$, and $4 \mathrm{~h})$. Incubated microcosms consisted of $9 \mathrm{~g}$ (oven dried basis) samples of sieved soils placed in $120 \mathrm{~mL}$ sterile glass flasks capped with butyl rubber stoppers and sealed with aluminum crimps. Microcosms were flushed with a sterilized $\mathrm{CO}_{2}$-free gas $\left(80 \% \mathrm{~N}_{2}, 20 \% \mathrm{O}_{2}\right)$ and incubated in the dark at $20^{\circ} \mathrm{C}$ for 91 days. Non-irradiated living soil was also incubated as a control. Three microcosm replicates per treatment were prepared. Flasks were sampled at 15, 31, 51, and 91 days of incubation to measure $\mathrm{CO}_{2}$ fluxes and ${ }^{13} \mathrm{C}$ abundance of $\mathrm{CO}_{2}$. After each measurement, flasks containing soil samples were flushed with a sterilized $\mathrm{CO}_{2}$-free gas $\left(80 \% \mathrm{~N}_{2}, 20 \% \mathrm{O}_{2}\right)$. All manipulations were done under sterile conditions. In the text and figures, LS means living soils, IS means irradiated soils, and IAS- $t$ refers to irradiated and autoclaved soils, with " $t$ " referring to the duration of autoclaving.

\subsection{Carbon dioxide emissions and their isotope composition $\left({ }^{13} \mathrm{C} /{ }^{12} \mathrm{C}\right)$}

The amount and isotope composition $\left(\delta^{13} \mathrm{C}\right)$ of $\mathrm{CO}_{2}$ accumulated in flasks during the incubation period were quantified using a cavity ring-down spectrometer analyzer coupled to a small sample injection module (SSIM) (Picarro G2101-i analyzer coupled to the SSIM, Picarro Inc., Santa Clara, California, USA). A volume of $20 \mathrm{~mL}$ gas was sampled by the analyzer. The $\mathrm{CO}_{2}$ concentration in gas samples ranged from 300 to $2000 \mathrm{ppm} \mathrm{CO}_{2}$ in accordance with the operating range of the analyzer. The $\mathrm{CO}_{2}$ concentrations and $\delta^{13} \mathrm{C}$ gas samples were measured at a frequency of $0.5 \mathrm{~Hz}$ for $10 \mathrm{~min}$. The value provided by the analyzer is the integrated value during these $10 \mathrm{~min}$ of measurement. A reference gas with a known concentration of $\mathrm{CO}_{2}$ and $\delta^{13} \mathrm{C}$ was injected between samples. For each period of incubation, the cumulated amount of 


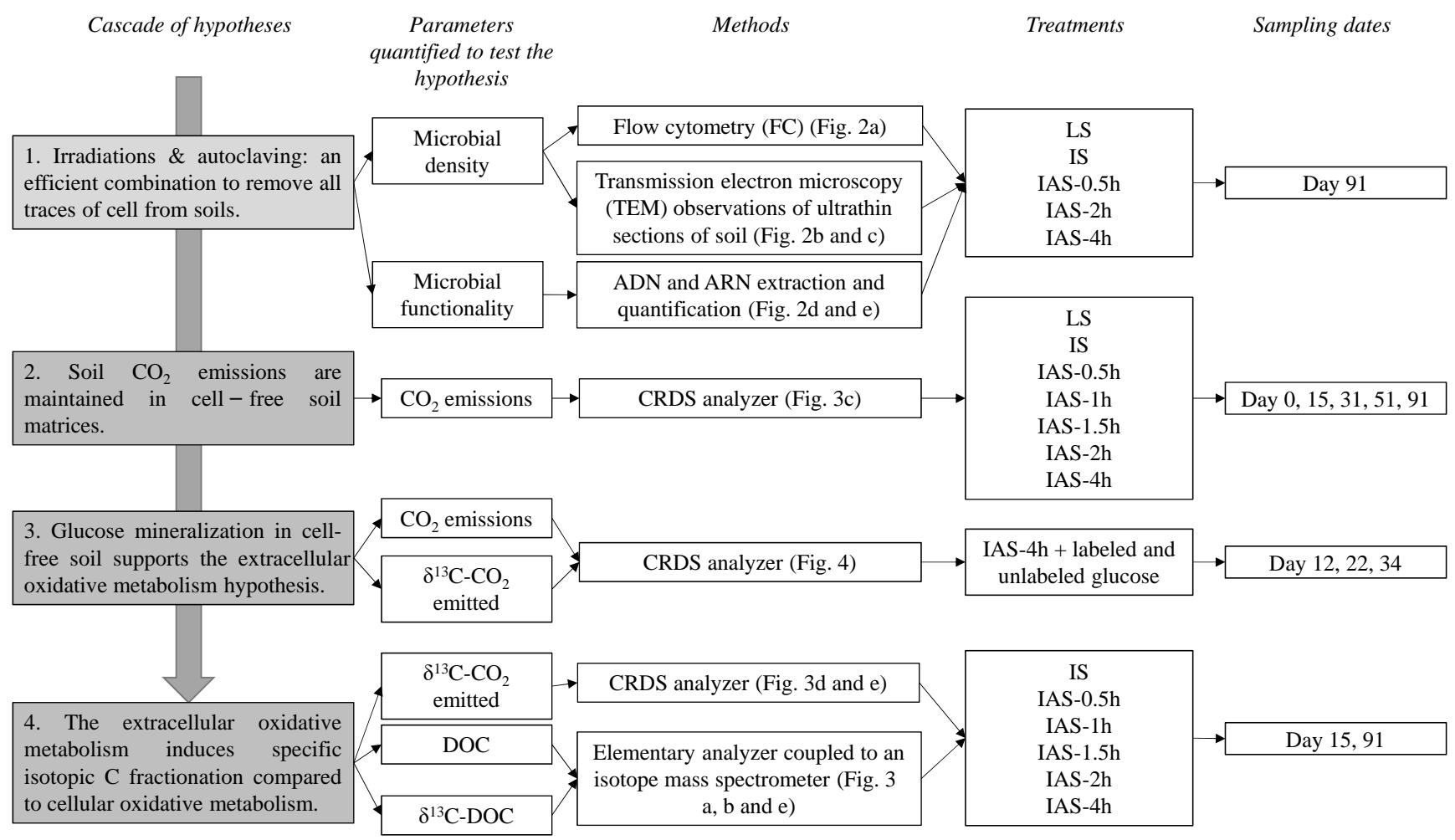

Figure 1. General experimental design of the study, including our hypotheses, parameters, methods, and the samples ( $n=3$ for each date and treatment studied) used to test these hypotheses.

$\mathrm{CO}_{2}$ was divided by the duration of the period (in days) to estimate the mean daily $\mathrm{CO}_{2}$ emission rate.

\subsection{Content and isotope composition of dissolved organic carbon (DOC)}

At the beginning and at the end of incubation $(t=15$ and $t=91$ days, respectively), DOC was extracted from $5 \mathrm{~g}$ of soil with a $30 \mathrm{mM} \mathrm{K} \mathrm{K}_{2} \mathrm{SO}_{4}$ solution. After filtration through Whatman ${ }^{\mathrm{TM}} 1.6 \mu \mathrm{m}$ glass microfiber filter extracts (GE Healthcare Life Sciences) were lyophilized. The lyophilized samples were analyzed with an elementary analyzer (Carlo Erba NA 1500) coupled to an isotope ratio mass spectrometer (Thermo Finnigan Delta $S$ ) to determine their carbon content and isotope composition $\left(\delta^{13} \mathrm{C}\right)$.

\subsection{Isotope systematic}

We use standard $\delta$ notation for quantifying the isotopic composition of $\mathrm{CO}_{2}$ and DOC; the ratio $R$ of ${ }^{13} \mathrm{C} /{ }^{12} \mathrm{C}$ in the measured sample is expressed as a relative difference (denoted $\delta^{13} \mathrm{C}$ ) from the Vienna Pee Dee Belemnite (VPDB) international standard material. The carbon isotope composition is expressed in parts per thousand $(\% \circ)$ according to the following expression: $\left.\delta^{13} \mathrm{C}=\left(R_{\text {sample }} / R_{\mathrm{VPDB}}\right)-1\right) \times 1000$. The carbon isotope fractionation was calculated as follows: $\Delta \delta^{13} \mathrm{C}(\%)=\left(\delta^{13} \mathrm{C}-\mathrm{DOC}-\delta^{13} \mathrm{C}-\mathrm{CO}_{2}\right) /\left(1+\delta^{13} \mathrm{C}-\mathrm{CO}_{2}\right)$.

\subsection{Soil cell density}

At the end of the incubation setting ( $t=91$ days), cells were separated from soil particles and enumerated by flow cytometry (FC). One gram of soil was mixed with $10 \mathrm{~mL}$ of pyrophosphate buffer (PBS 1X, $0.01 \mathrm{M} \mathrm{Na}_{4} \mathrm{P}_{2} \mathrm{O}_{7}$ ) and shaken for $30 \mathrm{~min}$ in ice at $70 \mathrm{rpm}$ on a rotary shaker. After shaking, the solution was sonicated three times $(1 \mathrm{~min}$ each) in a water bath sonicator (Fisher Scientific 88156, 320 W, Illkirch, France). Larger particles were removed by centrifugation $(800 \times g, 1 \mathrm{~min})$, the supernatant was fixed with paraformaldehyde ( $4 \%$ final concentration), and stored at $4{ }^{\circ} \mathrm{C}$ prior to quantification analysis. Total cell counts were performed using a FACSCalibur flow cytometer (BD Biosciences, San Jose, California, USA) equipped with an aircooled laser, providing $15 \mathrm{~mW}$ at $488 \mathrm{~nm}$ with the standard filter setup. Samples were diluted into $0.02 \mu \mathrm{m}$ filtered TE buffer, stained with SYBR Green 1 (10000-fold dilution of commercial stock, Molecular Probes, Oregon, USA), and the mixture was incubated for $15 \mathrm{~min}$ in the dark. The cellular abundance was determined on plots of side scatter versus green fluorescence $(530 \mathrm{~nm}$ wavelength, fluorescence channel 1 of the instrument. Each sample was analyzed for $1 \mathrm{~min}$ at a rate of $20 \mu \mathrm{L} \mathrm{min}{ }^{-1}$. FCM list modes were analyzed using CellQuest Pro software (BD Biosciences, version 4.0). Cell density was expressed as cells $\times \mathrm{g}^{-1}$ of soil (dry mass). 


\subsection{Density and integrity of cells}

At the end of the incubation setting ( $t=91$ days), abundance of unicellular organisms (prokaryotic and eukaryotic) with a preserved morphology were quantified on ultrathin soil sections ( $90 \mathrm{~nm}$ thick) by TEM. Each step of the soil inclusion protocol was followed by centrifugation $(12000 \times g, 2 \mathrm{~min})$ to pellet soil samples. Aliquots of the soil samples $(0.05 \mathrm{~g})$ were fixed for $1 \mathrm{~h}$ in $1.5 \mathrm{~mL}$ of a cacodylate buffer, $\mathrm{pH} 7.4$ (0.2 M cacodylate, $6 \%$ glutaraldehyde, and $0.15 \%$ ruthenium red). The soil was washed three times with cacodylate $0.1 \mathrm{M}$ buffer for $10 \mathrm{~min}$. Post fixation was conducted with the $0.1 \mathrm{M}$ cacodylate buffer containing $1 \%$ osmic acid. To facilitate the further penetration of propylene oxide, soil dehydration was made through a gradient of ethanol: $50 \%$ ethanol $(3 \times 5 \mathrm{~min}), 70 \%$ ethanol $(3 \times 15 \mathrm{~min})$ and $100 \%$ ethanol $(3 \times 20 \mathrm{~min})$ solutions. To improve the resin permeation, the sample was incubated in a propylene oxide bath $(3 \times 20 \mathrm{~min})$. To allow the sample to soak resin, the soil sample was incubated overnight in a bath containing propylene oxide and Epon 812 resin (ratio $1: 1$ ) and secondary eliminated by flipping. After polymerization of cast resin on soil preparations $\left(48 \mathrm{~h}, 50^{\circ} \mathrm{C}\right)$, the narrower parts of the molded and impregnated aggregates were pyramidally shaped with a Reichert TM60 ultramill and, finally, ultrathin sections $(90 \mathrm{~nm})$ were performed with a diamond knife (Ultra $45^{\circ}$, MF1845, DiATOME Ltd., Biel/Bienne, Switzerland; Ultramicrotome Ultracut S, Reichert Jung Leica, Austria). Soil cuts were collected onto 400-mesh Cu electron microscopy grids supported with carbon-coated Formvar film (Pelanne Instruments, Toulouse, France). Each grid was negatively stained for $30 \mathrm{~s}$ with uranyl acetate $(2 \%)$, rinsed twice with $0.02 \mu \mathrm{m}$ distilled water, and dried on filter paper. Soil ultrathin sections were analyzed using a JEM 1200-EX TEM (JEOL, Akishima, Japan). Abundance of morphologically intact cells were expressed as cells $\times \mathrm{mm}^{-2}$ of soil.

\subsection{Soil DNA and RNA content}

Two grams of soil were collected at the end of the incubation setting ( $t=91$ days). Genomic DNA and total RNA were extracted from soil samples and purified using the PowerSoil DNA and total RNA isolation kits (MO BIO Laboratories, Inc.), respectively. DNA and RNA content of soil communities were visualized by electrophoresis on $1 \%$ agarose gel containing ethidium bromide $\left(0.5 \mathrm{~g} \mathrm{~mL}^{-1}\right)$ normalized with a $1 \mathrm{kbp}$ size marker (Invitrogen). Negative control was also performed. Following electrophoresis, agarose gels were analyzed using ImageJ software (available at http://imagej.nih. gov/ij/). The band intensities were used to quantify the relative content of soil DNA and RNA in sterilized soils related to living soil.

\subsection{Soil incubations with ${ }^{13} \mathrm{C}_{6}$-labeled glucose}

Samples ( $9 \mathrm{~g}$, dry mass basis) of irradiated ( $45 \mathrm{kGy})$ and autoclaved $\left(121^{\circ} \mathrm{C}, 4 \mathrm{~h}\right)$ soil were incubated after addition of sterile solutions $(1.53 \mathrm{~mL} 0.086 \mathrm{M}$ glucose solution) of either unlabeled or ${ }^{13} \mathrm{C}_{6}$ glucose $\left({ }^{13} \mathrm{C}\right.$ abundance $\left.=99 \%\right)$. This amendment corresponds to $2.6 \mathrm{mg}$ glucose $\mathrm{g}^{-1}$ soil. Incubation and gas measurements were performed as previously described.

\subsection{Statistical analyses}

Each treatment was prepared in triplicate $(n=3)$. One-way ANOVA analysis was used to test the involvement significance of sterilization treatments on $\mathrm{CO}_{2}$ emissions, $\delta^{13} \mathrm{C}$ $\mathrm{CO}_{2}$, DOC, and $\delta^{13} \mathrm{C}$-DOC. Normality was tested using the Shapiro-Wilk test $(p>0.05)$. Equality of variances were tested with a Levene's test $(p<0.05)$. Student $t$ test analyses were used to test the significance of difference $(p<0.05)$ obtained between each condition. Those statistical analyses were performed using the Past software, version 3.04 (Hammer, 2001).

\section{Results}

\subsection{Effect of sterilization treatments}

\subsubsection{Microbial cell density, and soil DNA and RNA content}

Gamma-irradiation did not significantly reduce cellular density as revealed by flow cytometry $\left(3.1 \times 10^{8} \pm\right.$ $1.3 \times 10^{7}$ cell g$^{-1}$ in LS versus $3.2 \times 10^{8} \pm 1.1 \times 10^{8}$ cell g $^{-1}$ in IS; see Fig. $2 \mathrm{a})$ and TEM $\left(1.4 \times 10^{4} \pm 4.3 \times 10^{3}\right.$ in LS versus $9.5 \times 10^{3} \pm 0.7 \times 10^{2}$ cell g ${ }^{-1}$ in IS; see Fig. $2 b$ and c). However, two proxies of cellular functionality and activity (DNA and RNA) were substantially decreased by irradiation $(-93.5 \% \pm 1 \%$ for DNA and $-74 \% \pm 6 \%$ for RNA; see Fig. 2d and e). Moreover, RNA and DNA streaks observed on electrophoresis gels indicated that the nucleic acid content of irradiated soils was largely degraded (data not shown).

The combination of $\gamma$-irradiation and autoclaving decreased cell densities by 2 orders of magnitude in IAS (Fig. 2a). Results from flow cytometry and TEM showed that the cell density was reduced to $<2 \%$ compared to LS. After autoclaving, TEM revealed that the cell density was reduced to undetectable values (Fig. 2b). According to TEM and nucleic acid extract results (Fig. 2b, d, and e), the remaining flow cytometry signal in IAS is attributed to autofluorescent particles and unspecific binding of the fluorescent dyes on debris. 

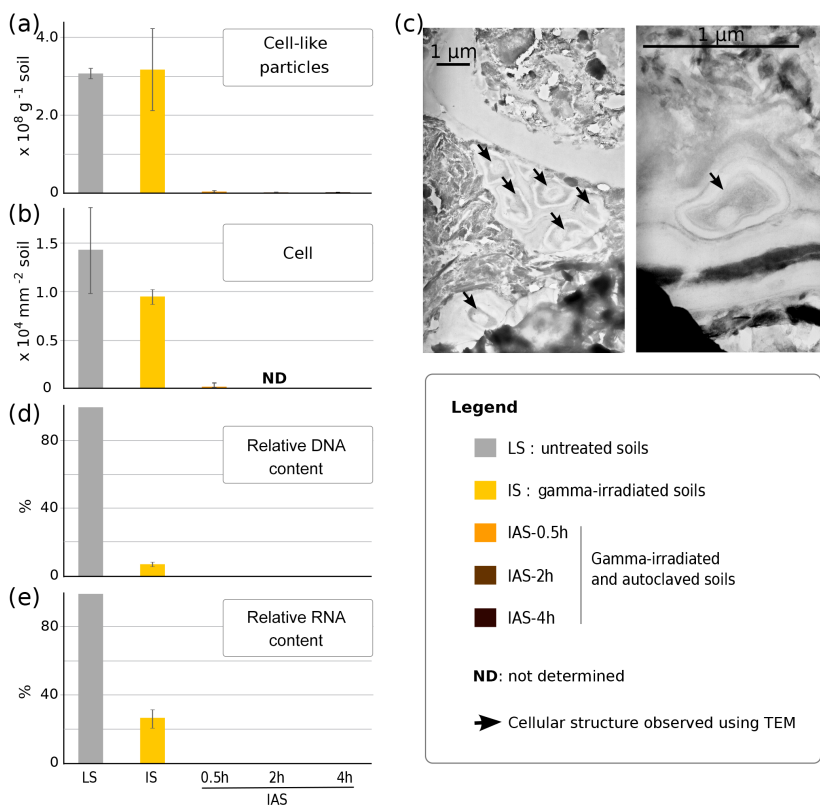

Figure 2. Impact of sterilization treatments on cellular density, integrity, and functionality. (a) Cell density enumerated by flow cytometry (FC), (b) cell density and integrity determined by transmission electron microscopy (TEM), (c) TEM photographs of ultrathin sections of soil showing cellular structure in LS, (d) relative DNA and (e) relative RNA content in soils (dry mass basis) in percentages estimated using LS as a reference. Values succeeding IAS refer to the duration of autoclaving. Standard deviation was estimated using three replicates per condition $(n=3)$.

\subsection{DOC and its isotopic composition}

Both $\gamma$-irradiation and autoclaving modified the soil chemistry as revealed by the analysis of the aqueous phase at the beginning of the experiment. The aqueous phase contained much more DOC in irradiated soil than in untreated soil $\left(37 \pm 3 \mu \mathrm{g} \mathrm{Cg} \mathrm{g}^{-1}\right.$ to $303 \pm 17 \mu \mathrm{g} \mathrm{Cg}^{-1}$ in LS and IS, respectively (Fig. 3a). Autoclaving further increased DOC content which gradually accumulated according to the duration of autoclaving from $557 \pm 11 \mu \mathrm{g} \mathrm{Cg}^{-1}$ with $0.5 \mathrm{~h}$ of autoclaving to $1060 \pm 28.4 \mu \mathrm{g} \mathrm{Cg}^{-1}$ after $4 \mathrm{~h}$ of autoclaving (Fig. 3a). Similarly, the $\delta^{13} \mathrm{C}$-DOC gradually increased from $-27.4 \pm 0.4 \%$ in LS to $-24.9 \pm 0.12 \%$ in IAS- $4 \mathrm{~h}$ (Fig. $3 \mathrm{~b}$ ). In all soil microcosms, DOC content and $\delta^{13} \mathrm{C}$ of DOC did not significantly change over time (data not shown).

All soil microcosms emitted $\mathrm{CO}_{2}$ throughout the incubation (Fig. 3c). The daily $\mathrm{CO}_{2}$ emission rate increased significantly $(p<0.05)$ with time in LS, whereas it gradually declined in IS (Fig. 3c). All IAS microcosms exhibited similar dynamics of daily $\mathrm{CO}_{2}$ emission rate; the high daily- $\mathrm{CO}_{2}$ emission rate recorded during the first period of incubation (0-15 days), strongly decreased during the second period (15-31 days), and stabilized thereafter (Fig. 3c).
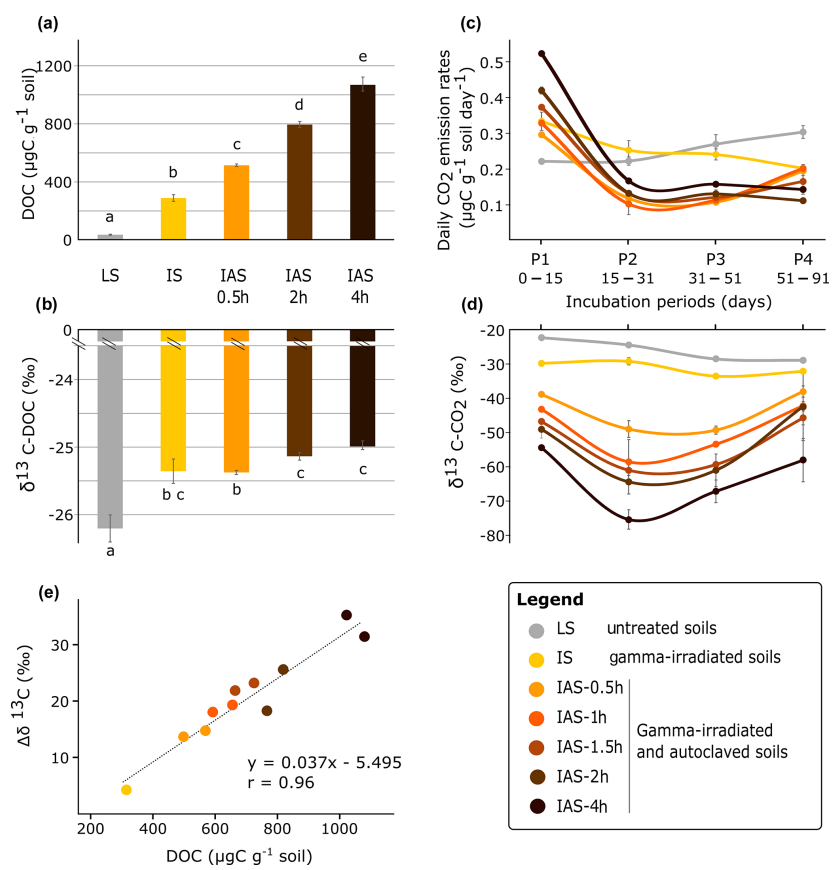

Figure 3. Content and isotopic composition of both dissolved organic carbon (DOC) and $\mathrm{CO}_{2}$ across time and treatments. (a) Content of DOC and (b) $\delta^{13} \mathrm{C}$-DOC at the beginning of incubation, (c) daily $\mathrm{C}-\mathrm{CO}_{2}$ emission rates and (d) $\delta^{13} \mathrm{C}$ of $\mathrm{CO}_{2}$ released during four periods of incubation, and (e) correlation between the carbon isotope discrimination $\left(\Delta \delta^{13} \mathrm{C}\right.$ in $\%$ o ) induced by the extracellular oxidative metabolism (EXOMET) and the DOC content. The correlation was calculated from sterilized soil treatment data (IS and IAS- $0.5 \mathrm{~h}$, IAS- $1 \mathrm{~h}$, IAS- $1.5 \mathrm{~h}$, IAS- $2 \mathrm{~h}$, and IAS- $4 \mathrm{~h}$ ) analyzed at the beginning and end of incubation. Standard deviation was estimated using three replicates per condition $(n=3)$.

Cumulated $\mathrm{CO}_{2}$ emissions from LS and IS were not significantly $(p<0.05)$ different throughout the 91 days

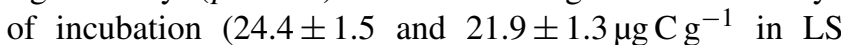
and IS, respectively) but were significantly $(p<0.05)$ higher than cumulated $\mathrm{CO}_{2}$ emissions from IAS treatments $\left(16.8 \pm 1.5 \mu \mathrm{g} \mathrm{Cg}^{-1}\right)$ (data not shown). The duration of autoclaving has no effect on cumulated $\mathrm{CO}_{2}$ emissions. At the end of the incubation, the percentage of initial DOC oxidized to $\mathrm{CO}_{2}$ was low for all sterilized soils $(<7.2 \%)$ and decreased with the duration of autoclaving (from 2.9 to $1.8 \%$ for IAS- $0.5 \mathrm{~h}$ and IAS- $4 \mathrm{~h}$, respectively) (see Supplement Fig. S1).

The $\delta^{13} \mathrm{C}_{-} \mathrm{CO}_{2}$ from LS decreased with time from $-22.2 \pm 0.1 \%$ o to $-28.9 \pm 0.3 \%$ o. The $\delta^{13} \mathrm{C}^{-\mathrm{CO}_{2}}$ strongly decreased with the intensity of sterilization treatments from $-29.2 \pm 1 \%$ in IS to $-75.4 \pm 2.8 \%$ in IAS with $4 \mathrm{~h}$ of autoclaving (Fig. 3d). This pattern of values was maintained throughout the incubation but the difference of $\delta^{13} \mathrm{C}_{-} \mathrm{CO}_{2}$ between living and sterilized soils was maximal during the two intermediate periods ( $\mathrm{P} 2$ and $\mathrm{P} 3$ ). 


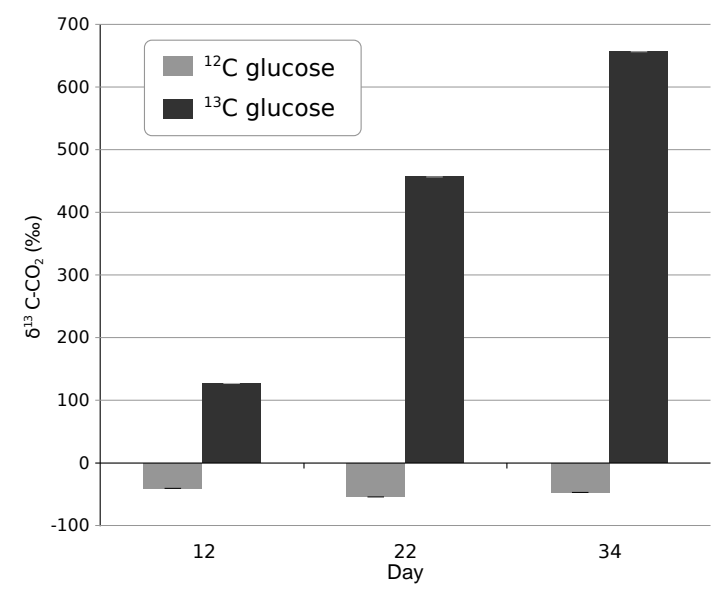

Figure 4. Kinetic of the $\delta^{13} \mathrm{C}-\mathrm{CO}_{2}$ released from an irradiated and autoclaved $(4 \mathrm{~h})$ soil inoculated with ${ }^{13} \mathrm{C}$-labeled glucose $\left({ }^{13} \mathrm{C}\right.$ glucose) or with unlabeled glucose $\left({ }^{12} \mathrm{C}\right.$ glucose) through 34 days of incubation. Standard deviation was estimated using three replicates per treatment $(n=3)$.

\subsection{Carbon isotope fractionation during DOC mineralization}

The $\delta^{13} \mathrm{C}$ strongly deviated between DOC and $\mathrm{CO}_{2}$ in all sterilized soil microcosms (Fig. 3e) indicating substantial C isotope fractionation during DOC mineralization. This isotope fractionation gradually increased with the intensity of the autoclaving treatment from $13.2 \pm 0.7 \%$ in IAS with $0.5 \mathrm{~h}$ of autoclaving to $31 \pm 2.5 \% \mathrm{in}$ IAS with $4 \mathrm{~h}$ of autoclaving. The isotope fractionation was significantly and positively correlated to the DOC content ( $r=0.96$; see Fig. 3e). The $\delta^{13} \mathrm{C}$ deviation between DOC and $\mathrm{CO}_{2}$ in $\mathrm{LS}$ was $<4 \%$ o (data not shown).

\subsection{Response of sterilized soil to the supply of unlabeled and ${ }^{13} \mathrm{C}_{6}$-labeled glucose}

The supply of unlabeled or labeled glucose in IAS with $4 \mathrm{~h}$ of autoclaving did not significantly change total $\mathrm{CO}_{2}$ emissions (data not shown). The $\delta^{13} \mathrm{C}$ values of $\mathrm{CO}_{2}$ released from microcosms with unlabeled glucose ranged from $-40.2 \pm 0.6 \%$ o to $-53.8 \pm 1.2 \%$ (Fig. 4). The $\mathrm{CO}_{2}$ released from microcosms with ${ }^{13} \mathrm{C}$ glucose showed progressive ${ }^{13} \mathrm{C}$ enrichment with time from $\delta^{13} \mathrm{C}=127.8 \pm 1.3 \%$ o to $657 \pm 1.7 \%$ after 12 and 34 days of incubation, respectively (Fig. 4). At the end of the incubation, the amount of ${ }^{13} \mathrm{C}$ glucose released as $\mathrm{CO}_{2}$ corresponded to $0.01 \%$ glucose input.

\section{Discussion}

\subsection{Irradiation and autoclaving: an efficient combination to remove all traces of cell from soils}

Demonstrating that complex soil matrices are truly devoid of intact cells is a challenging task. In previous studies, measures for assessing abundance and activity of cells in $\gamma$ irradiated soils ranged from cultivation (Blankinship et al., 2014; Maire et al., 2013), live-dead staining (Blankinship et al., 2014), fluorescent in situ hybridization (Maire et al., 2013), biomass estimation (Maire et al., 2013) to biomarkers concentrations (Buchan et al., 2012). All gave the same conclusion: a high proportion of dead but intact cells remained after $\gamma$-irradiation of soil samples (Blankinship et al., 2014; Lensi et al., 1991; Maire et al., 2013). We found a similar result using flow cytometry, TEM, and estimation of DNA and RNA content of soil (Fig. 2).

To remove the remaining cells, we combined $\gamma$-irradiation with a time gradient of autoclaving to analyze the kinetics of microbial cellular lysis. To ensure that no cells with a preserved morphology remained in soil aggregates we performed in situ observations with TEM on tangential ultrathin sections of soil. This approach avoids the pitfalls of methods involving dilute suspensions of soil extracts (i.e. incomplete elution of microorganisms ( $\mathrm{Li}$ et al., 2004). The combination of both sterilization treatments allowed suppression of all observable cell structures (Fig. 2). Our results also indicate that the sterility of soil microcosms was maintained until the end of incubation.

By destroying the microbial biomass and releasing its content in soil, the sterilization treatments led to an accumulation of DOC (Fig. 3a). The increasing DOC accumulation with increasing duration of autoclaving likely resulted from desorption of organic carbon from soil particles (Berns et al., 2008) and/or from depolymerization of carbohydrates (Tuominen et al., 1994) since microbial biomass was mostly lysed after $0.5 \mathrm{~h}$ of autoclaving.

\subsection{Body of evidence for EXOMET}

The irradiated and autoclaved soils showed persistent (>91 days) and substantial soil $\mathrm{CO}_{2}$ emissions (50-80\% $\mathrm{CO}_{2}$ emissions compared to LS). Those $\mathrm{CO}_{2}$ emissions can hardly be ascribed to residual activities of living and "ghost" cells since the sterilizing treatments removed all observable cell structure. Moreover, the substantial $\mathrm{C}$ isotope fractionation (from 13 to $35 \%$; see Fig. 3e) induced by the process responsible for $\mathrm{CO}_{2}$ emissions is incompatible with respiration of cellular origin. A substantial contribution of soil carbonates to $\mathrm{CO}_{2}$ emissions is unlikely because (i) the inorganic carbon pool is very small in the acidic soil used in this study (Fontaine et al., 2007) and (ii) the isotopic composition of $\mathrm{CO}_{2}$ did not reflect the signature of soil carbonates (Bertrand et al., 2007). The decarboxylation of organic compounds by 
a combustion induced by sterilization treatments is also excluded because (i) $\mathrm{CO}_{2}$ emissions were persistent throughout the incubation and (ii) the $\mathrm{C}$ isotope fractionation during organic $\mathrm{C}$ combustion is typically weak $(\sim 3 \%$ ) (Turney et al., 2006). Finally, irradiation and heating induce a heavy oxidative stress through the formation of hydroperoxides, carboxyls and free radicals. These highly reactive oxidants can lead to organic matter oxidation and decarboxylation. However, this oxidative process can hardly explain the persistent $\mathrm{CO}_{2}$ emissions observed in our experiment since the halflife of highly reactive oxidants is extremely short (i.e. $10^{-9} \mathrm{~s}$ for free radicals). Moreover, Blankinship et al. (2014) have shown that the persistence of soil $\mathrm{CO}_{2}$ emissions after microbial biomass suppression (or at least reduction) is not specific to irradiated soil but also occurs with other methods of sterilization such as chloroform fumigation and autoclaving.

The most parsimonious explanation of persistence of $\mathrm{CO}_{2}$ emissions (Fig. 3c) and $\mathrm{O}_{2}$ consumption (Maire et al., 2013) after soil sterilization is an EXOMET. By EXOMET, we suggest a cascade of chemical reactions where electrons are transferred from organic matter to redox mediators (i.e. $\mathrm{NAD}^{+} / \mathrm{NADH}, \mathrm{Mn}^{3+} / \mathrm{Mn}^{2+}$ ) and finally to $\mathrm{O}_{2}$. Those reactions can be catalyzed by respiratory enzymes stabilized on soil particles (Maire et al., 2013), and by minerals and metals present in soil (Blankinship et al., 2014; Majcher et al., 2000). The evidence of a complex oxidative metabolism is supported by the oxidation of ${ }^{13} \mathrm{C}$ glucose to ${ }^{13} \mathrm{CO}_{2}$ (Fig. 4). Indeed, glucose is a stable molecule which must undergo many biochemical transformations before being oxidized to $\mathrm{CO}_{2}$. The glucose decarboxylation (Fig. 4) and concurrent $\mathrm{O}_{2}$ consumption (Maire et al., 2013) suggest that EXOMET is able to reconstitute an equivalent of glycolysis and the Krebs cycle.

Mineral catalysts are stable and soil-stabilized enzymes are protected against denaturation (Carter et al., 2007; Gianfreda and Ruggiero, 2006; Nannipieri, 2006; Nannipieri et al., 1996; Stursova and Sinsabaugh, 2008). This stability of soil catalysts likely contributes to the maintenance of glucose oxidation and $\mathrm{CO}_{2}$ emissions after soil exposure to high temperature and pressure (autoclaving). Maire et al. (2013) have already pointed at the exceptional resistance of soil $\mathrm{CO}_{2}$ emissions to high temperature, pressure, and toxins. However, by providing here the evidence of an oxidation of ${ }^{13} \mathrm{C}$ labeled glucose in $\gamma$-sterilized soil exposed to high temperature and pressure, we show that the complex metabolic pathways of the EXOMET are maintained under these extreme conditions.

\subsection{Origin of $\mathrm{C}$ isotope fractionation during EXOMET}

Our results indicated that the EXOMET preferentially oxidizes organic molecules containing light $\left({ }^{12} \mathrm{C}\right)$ over heavy $\left({ }^{13} \mathrm{C}\right)$ carbon atoms. Similar strong isotope fractionation has already been described during wet abiotic oxidation of oxalic acid (Grey et al., 1969). The preferential conversion of substrates containing lighter isotopes is in agreement with classical kinetic and thermodynamic laws. The presence of

${ }^{13} \mathrm{C}$ atoms in a substrate slows its conversion rate because of the higher activation energy request to induce the reaction (Christensen and Nielsen, 2000; Heinzle et al., 2008). Classical works on thermodynamics also indicate that the isotopic fractionation is dependent on substrate concentration (Agren et al., 1996; Goevert and Conrad, 2009; Wang et al., 2015). Under limited substrate concentration, the isotope fractionation decreases because the heavy molecules left over during the first stages of reaction are finally carried out by the process. Consistently, the isotopic fractionation induced by the EXOMET was quantified with an excess of substrates (S1). Moreover, the magnitude of isotope fractionation was positively correlated to DOC content (Fig. 2e). However, the causal link between the magnitude of fractionation and the DOC content is not certain since the correlation emerges from a compilation of results obtained after different sterilization treatments. Further studies should analyze this causal link in experiments where the DOC content is directly manipulated.

Previous studies (Blair et al., 1985; Zyakun et al., 2013) have shown that, contrary to EXOMET, cells induce few $(<4 \%$ o) or no $\mathrm{C}$ isotope fractionation during respiration. This difference between cell respiration and EXOMET can be explained by two processes. First, substrate absorption by microbial cells is typically limited by substrate diffusion, a process that does not fractionate or weakly fractionates isotopes. Second, cells maintain a limited quantity of substrates in the cytoplasm by regulating their substrate absorption and reserves (Button, 1998). This limited substrate availability prevents the preferential use of light $\mathrm{C}$ isotopes during biochemical reactions of cell respiration.

It is well-known that the $\delta^{13} \mathrm{C}$ of $\mathrm{CO}_{2}$ emitted from soils shows circadian cycle and seasonal fluctuations that reaches up to 5\%o (Moyes et al., 2010). However, it is difficult to link these fluctuations to a modification of metabolic pathways of soil respiration (living respiration versus EXOMET) in response to environmental changes since numerous other processes can contribute to these fluctuations. Moreover, it is likely that the EXOMET does not induce much $\mathrm{C}$ isotope fractionation in non-sterilized soils since the DOC content is typically low (Fig. 3a) (Liu et al., 2015). Therefore, addition of large amounts of DOC is necessary to reveal the $\mathrm{C}$ fractionation induced by the EXOMET in non-sterilized soils.

\subsection{Towards a quantification of EXOMET and cellular respiration in living soils}

Our findings support the idea that $\mathrm{CO}_{2}$ emissions from soils are driven by two major oxidative metabolisms: (1) the wellknown respiration of soil biota and (2) an EXOMET carried out by soil stabilized enzymes and soil minerals and metals. A first quantification of these metabolisms has been made by Maire et al. (2013) suggesting that the EXOMET contributes 
from 16 to $48 \%$ of soil $\mathrm{CO}_{2}$ emissions. However, Maire et al. (2013) pointed at the need of another method to confirm this substantial contribution of the EXOMET. Indeed, their method can lead to some biases. For instance, the soil irradiation used to block cellular activities and estimate the EXOMET induces a flush of respiration due to the release of substrates and enzymes from microbial biomass. This side effect of soil sterilization leads to an overestimation of the EXOMET by releasing enzymes and cofactors in soil.

The difference in $\mathrm{C}$ isotope fractionation between the EXOMET and cellular respiration offers another method of quantification of those metabolisms applicable to nonsterilized living soils. The development of this method first requires a quantification of the isotope fractionation $\left(\Delta^{13} \mathrm{C}\right)$ and its dependence on DOC content occurring during cell respiration $\left(\Delta^{13} \mathrm{C}_{\text {cell }}\right)$ and EXOMET $\left(\Delta^{13} \mathrm{C}_{\text {EXOMET }}\right)$. Our results provide an example of estimation of $\Delta^{13} C_{\text {EXOMET }}$ (Fig. 3e), though further studies are needed to verify the genericity of this estimation in other soils. $\Delta^{13} C_{\text {cell }}$ for soil microorganisms can be estimated from cell cultures using soil inoculum and different substrate concentrations. This quantification allows determination of the isotope composition of $\mathrm{CO}_{2}\left(\delta^{13} \mathrm{C}-\mathrm{CO}_{2}\right)$ released by cell respiration $\left(\delta^{13} \mathrm{C}-\mathrm{CO}_{2 \text { cell }}\right)$ and EXOMET $\left(\delta^{13} \mathrm{C}-\mathrm{CO}_{2}\right.$ EXOMET $)$ in function to DOC content and isotope composition of DOC $\left(\delta^{13} \mathrm{C}\right.$ $\mathrm{DOC}_{\text {sample}}$ ) as shown in the following equations:

$\delta^{13} \mathrm{C}-\mathrm{CO}_{2 \text { cell }}=\delta^{13} \mathrm{C}-\mathrm{DOC}_{\text {sample }}-\Delta^{13} \mathrm{C}_{\text {cell }}$,

$\delta^{13} \mathrm{C}-\mathrm{CO}_{2}$ EXOMET $=\delta^{13} \mathrm{C}-\mathrm{DOC}-\Delta^{13} \mathrm{C}_{\text {EXOMET }}$,

where $\Delta{ }^{13} \mathrm{C}_{\text {cell }}$ and $\Delta{ }^{13} \mathrm{C}_{\text {EXOMET }}$ are functions of DOC content. Based on our results, $\Delta{ }^{13} \mathrm{C}_{\text {EXOMET }}$ can be determined by

$\Delta^{13} \mathrm{C}_{\text {EXOMET }}=0.037 \times[\mathrm{DOC}]-5.495$,

where [DOC] is dissolved organic $\mathrm{C}$ content ( $\mu \mathrm{C} \mathrm{Cg}^{-1}$ soil).

Given that the $\mathrm{C}$ isotope fractionation depends on an excess of available substrate, substantial amounts of DOC must be added to the living soil before quantifying EXOMET and cell respiration. After substrate addition, cellular respiration $\left(R_{\text {cell }}\right)$ and EXOMET ( $\left.R_{\text {EXOMET }}\right)$ can be separated using the classical isotope mass balance equations as follows:

$$
\begin{aligned}
& R_{\text {soil }}=R_{\text {cell }}+R_{\text {EXOMET }}, \\
& \delta^{13} \mathrm{C}-\mathrm{CO}_{2 \text { soil }} \times R_{\text {soil }}=\delta^{13} \mathrm{C}-\mathrm{CO}_{2 \text { cell }} \times R_{\text {cell }} \\
& \quad+\delta^{13} \mathrm{C}-\mathrm{CO}_{2 \text { EXOMET }} \times R_{\text {EXOMET }},
\end{aligned}
$$

where $R_{\text {soil }}$ and $\delta^{13} \mathrm{C}_{-} \mathrm{CO}_{2}$ soil are, respectively, the total $\mathrm{CO}_{2}$ emitted by the amended soil ( $\mu \mathrm{g} \mathrm{C}-\mathrm{CO}_{2} \mathrm{~kg}^{-1}$ soil) and its isotopic composition $\left(\delta^{13} \mathrm{C}-\mathrm{CO}_{2}\right) . R_{\text {soil }}$ and $\delta^{13} \mathrm{C}-\mathrm{CO}_{2}$ soil must be measured in the hours following the substrate addition before any substantial growth of soil microorganisms which would lead to an over-estimation of cell respiration.
This short-term measurement is also a prerequisite to prevent the microbial uptake of the heavy $\mathrm{C}$ isotope left over by the EXOMET. $\delta^{13} \mathrm{C}-\mathrm{CO}_{2 \text { cell }}$ and $\delta^{13} \mathrm{C}-\mathrm{CO}_{2}$ EXOMET must be estimated in separate experiments, as previously described. Therefore, the two unknowns $R_{\text {cell }}$ and $R_{\text {EXOMET }}$ can be determined by solving the two equations.

\section{Conclusions and implications}

Collectively, our results tend to sustain the hypothesis through which soil $\mathrm{C}$ mineralization is driven by the wellknown process of microbial mineralization and an EXOMET carried out by soil-stabilized enzymes, and by soil mineral and metal catalysts. These two metabolisms may explain why soil C mineralization is not always connected to size and composition of the microbial biomass (Kemmitt et al., 2008), and why experimental reduction of these microbial components has moderate effects on mineralization rate (Griffiths et al., 2001). Moreover, these two metabolisms should be considered separately when studying effects of environmental factors on the $\mathrm{C}$ cycle because they are not likely to obey the same laws and respond differently to environmental factors. Soil microorganisms have tight physiological constraints comprising specific environmental conditions (temperature, moisture) and needs in energy and nutrients. The EXOMET is resistant to extreme conditions (e.g. autoclaving) thanks to soil stabilization of enzymes and depends on microbial turnover for the supply of respiratory enzymes. These two metabolisms may interact in many different ways: microbial cells and EXOMET likely compete for available substrates and/or dying cells are a source of respiratory enzymes and substrate for the EXOMET etc. Further studies are necessary to better understand processes at play and predict the relative importance of EXOMET and cell respiration across ecosystems and climates.

Overall our findings have several implications for biology. They challenge the belief of the cell as the minimum structure unit able to organize and achieve cascades of chemical reactions leading to complete oxidation of organic matter. Our findings also suggest that soils have played a key role in the origin of life. Previous studies have shown the role of soil minerals in the concentration and polymerization of amino acids and nucleic acids in protein-like molecules during the prebiotic period (Hazen, 2006; Bernal, 1949). Our results show that, when all relevant molecules are present, complex biochemical reactions underpinning the bioenergetics of life (respiration) can occur spontaneously in the soil. Thus, the first ancestral oxidative metabolisms may have occurred in soil before they were incorporated in the first cell. 


\section{Data availability}

The data are available from the corresponding author.

\section{The Supplement related to this article is available online at doi:10.5194/bg-13-6353-2016-supplement.}

Author contributions. This work arose from an idea of Sébastien Fontaine and Anne Catherine Lehours. Benoit Kéraval, Sébastien Fontaine, Anne Catherine Lehours, Gaël Alvarez and Christian Amblard designed the experiment. Benoit Kéraval and Jonathan Colombet conducted the experiments. Benoit Kéraval analyzed the data. Sébastien Fontaine identified the $\mathrm{C}$ isotope fractionation and conceived the model of quantification. Benoit Kéraval, Sébastien Fontaine, Anne Catherine Lehours, Gaël Alvarez and Christian Amblard cowrote the paper.

Competing interests. The authors declare no conflict of interest.

Acknowledgements. This work was supported by the project "Adaptation and responses of organisms and carbon metabolism to climate change" of the CPER program (French Ministry of Research, CNRS, INRA, Région Auvergne, FEDER) and by the project EXCEED of the PICS (CNRS) program. B. Kéraval was supported by a PhD fellowship from the Région Auvergne and FEDER.

Edited by: E. Pendall

Reviewed by: two anonymous referees

\section{References}

Agren, G. I., Bosatta, E., and Balesdent, J.: Isotope discrimination during decomposition of organic matter: A theoretical analysis, Soil Sci. Soc. Am. J., 60, 1121-1126, 1996.

Bernal, J. D.: The Physical Basis of Life, P. Phys. Soc. B, 62, 597618, doi:10.1088/0370-1301/62/10/301, 1949.

Berns, A. E., Philipp, H., Narres, H.-D., Burauel, P., Vereecken, H., and Tappe, W.: Effect of gamma-sterilization and autoclaving on soil organic matter structure as studied by solid state NMR, UV and fluorescence spectroscopy, Eur. J. Soil Sci., 59, 540-550, doi:10.1111/j.1365-2389.2008.01016.x, 2008.

Bertrand, I., Delfosse, O., and Mary, B.: Carbon and nitrogen mineralization in acidic, limed and calcareous agricultural soils: Apparent and actual effects, Soil Biol. Biochem., 39, 276-288, doi:10.1016/j.soilbio.2006.07.016, 2007.

Blair, N., Leu, A., Muñoz, E., Olsen, J., Kwong, E., and Des Marais, D.: Carbon isotopic fractionation in heterotrophic microbial metabolism, Appl. Environ. Microb., 50, 996-1001, 1985.
Blankinship, J. C., Becerra, C. A., Schaeffer, S. M., and Schimel, J. P.: Separating cellular metabolism from exoenzyme activity in soil organic matter decomposition, Soil Biol. Biochem., 71, 6875, doi:10.1016/j.soilbio.2014.01.010, 2014.

Buchan, D., Moeskops, B., Ameloot, N., De Neve, S., and Sleutel, S.: Selective sterilisation of undisturbed soil cores by gamma irradiation: Effects on free-living nematodes, microbial community and nitrogen dynamics, Soil Biol. Biochem., 47, 10-13, doi:10.1016/j.soilbio.2011.12.014, 2012.

Burns, R. G., DeForest, J. L., Marxsen, J., Sinsabaugh, R. L., Stromberger, M. E., Wallenstein, M. D., Weintraub, M. N., and Zoppini, A.: Soil enzymes in a changing environment: Current knowledge and future directions, Soil Biol. Biochem., 58, 216234, doi:10.1016/j.soilbio.2012.11.009, 2013.

Button, D. K.: Nutrient Uptake by Microorganisms according to Kinetic Parameters from Theory as Related to Cytoarchitecture, Microbiol. Mol. Biol. R., 62, 636-645, 1998.

Carter, D. O., Yellowlees, D., and Tibbett, M.: Autoclaving kills soil microbes yet soil enzymes remain active, Pedobiologia, 51, 295-299, doi:10.1016/j.pedobi.2007.05.002, 2007.

Christensen, B. and Nielsen, J.: Metabolic network analysis. A powerful tool in metabolic engineering, Adv. Biochem. Eng. Biot., 66, 209-231, 2000.

Fontaine, S., Barot, S., Barré, P., Bdioui, N., Mary, B., and Rumpel, C.: Stability of organic carbon in deep soil layers controlled by fresh carbon supply, Nature, 450, 277-280, doi:10.1038/nature06275, 2007.

Gianfreda, L. and Ruggiero, P.: Enzyme Activities in Soil, in Nucleic Acids and Proteins in Soil, edited by: Nannipieri, P. P., and Smalla, D. K., Springer, Berlin, Heidelberg, 257-311, 2006.

Goevert, D. and Conrad, R.: Effect of substrate concentration on carbon isotope fractionation during acetoclastic methanogenesis by Methanosarcina barkeri and M. acetivorans and in rice field soil, Appl. Environ. Microb., 75, 2605-2612, doi:10.1128/AEM.02680-08, 2009.

Grey, D. C., Damon, P. E., Haynes, C. V. and Long, A.: Carbonisotope fractionation during wet oxidation of oxalic acid, Radiocarbon, 11, 1-2, 1969.

Griffiths, B. S., Ritz, K., Wheatley, R., Kuan, H. L., Boag, B., Christensen, S., Ekelund, F., Sørensen, S. J., Muller, S., and Bloem, J.: An examination of the biodiversity-ecosystem function relationship in arable soil microbial communities, Soil Biol. Biochem., 33, 1713-1722, doi:10.1016/S0038-0717(01)00094-3, 2001.

Hammer, Ø., Harper, D. A. T., and Ryan, P. D.: PAST: Palaeontological Statistics Software package for education and data analysis, Palaeontol. Electron., 4, 1-9, 2001.

Hazen, R. M.: Presidential Address to the Mineralogical Society of America, Salt Lake City, October 18, 2005 Mineral surfaces and the prebiotic selection and organization of biomolecules, Am. Mineral., 91, 1715-1729, doi:10.2138/am.2006.2289, 2006.

Heinzle, E., Yuan, Y., Kumar, S., Wittmann, C., Gehre, M., Richnow, H.-H., Wehrung, P., Adam, P., and Albrecht, P.: Analysis of $13 \mathrm{C}$ labeling enrichment in microbial culture applying metabolic tracer experiments using gas chromatographycombustion-isotope ratio mass spectrometry, Anal. Biochem., 380, 202-210, doi:10.1016/j.ab.2008.05.039, 2008.

IPCC: Changes in atmospheric constituents and in radiative forcing. Climate Change 2007: The Physical Science Basis, Contribution of Working Group I to the Fourth Assessment Report of the In- 
tergovernmental Panel on Climate Change, edited by: Solomon, S., Qin, D., Manning, M., Chen, Z., Marquis, M., Averyt, K. B., Tignor, M., and Miller, H. L., Cambridge University Press, Cambridge, UK and New York, NY, USA, 130-234, 2007.

Junge, W., Lill, H., and Engelbrecht, S.: ATP synthase: an electrochemical ransducer with rotatory mechanics, Trends Biochem. Sci., 22, 420-423, doi:10.1016/S0968-0004(97)01129-8, 1997.

Kemmitt, S. J., Lanyon, C. V., Waite, I. S., Wen, Q., Addiscott, T. M., Bird, N. R. A., O’Donnell, A. G., and Brookes, P. C.: Mineralization of native soil organic matter is not regulated by the size, activity or composition of the soil microbial biomass - a new perspective, Soil Biol. Biochem., 40, 61-73, doi:10.1016/j.soilbio.2007.06.021, 2008.

Lensi, R., Lescure, C., Steinberg, C., Savoie, J.-M., and Faurie, G.: Dynamics of residual enzyme activities, denitrification potential, and physico-chemical properties in a $\gamma$-sterilized soil, Soil Biol. Biochem., 23, 367-373, doi:10.1016/0038-0717(91)90193N, 1991.

Li, D., Velde, B., and Zhang, T.: Observations of pores and aggregates during aggregation in some clay-rich agricultural soils as seen in 2D image analysis, Geoderma, 118, 191-207, doi:10.1016/S0016-7061(03)00193-9, 2004.

Liu, E., Chen, B., Yan, C., Zhang, Y., Mei, X., and Wang, J.: Seasonal Changes and Vertical Distributions of Soil Organic Carbon Pools under Conventional and No-Till Practices on Loess Plateau in China, Soil Sci. Soc. Am. J., 79, 517-526, doi:10.2136/sssaj2014.02.0069, 2015.

Maire, V., Alvarez, G., Colombet, J., Comby, A., Despinasse, R., Dubreucq, E., Joly, M., Lehours, A.-C., Perrier, V., Shahzad, T., and Fontaine, S.: An unknown oxidative metabolism substantially contributes to soil $\mathrm{CO}_{2}$ emissions, Biogeosciences, 10 , 1155-1167, doi:10.5194/bg-10-1155-2013, 2013.

Majcher, E. H., Chorover, J., Bollag, J.-M., and Huang, P. M.: Evolution of $\mathrm{CO}$ during Birnessite-Induced Oxidation of C-Labeled Catechol, Soil Sci. Soc. Am. J., 64, 157-163, doi:10.2136/sssaj2000.641157x, 2000.

Moyes, A. B., Gaines, S. J., Siegwolf, R. T. W., and Bowling, D. R.: Diffusive fractionation complicates isotopic partitioning of autotrophic and heterotrophic sources of soil respiration, Plant Cell Environ., 33, 1804-1819, doi:10.1111/j.13653040.2010.02185.x, 2010.

Nannipieri, P.: Role of Stabilised Enzymes in Microbial Ecology and Enzyme Extraction from Soil with Potential Applications in Soil Proteomics, in Nucleic Acids and Proteins in Soil, edited by: Nannipieri, P. P. and Smalla, D. K., Springer, Berlin, Heidelberg, 75-94, 2006.
Nannipieri, P., Sastre, I., Landi, L., Lobo, M. C., and Pietramellara, G.: Determination of extracellular neutral phosphomonoesterase activity in soil, Soil Biol. Biochem., 28, 107-112, doi:10.1016/0038-0717(95)00108-5, 1996.

Paterson, E. and Sim, A.: Soil-specific response functions of organic matter mineralization to the availability of labile carbon, Glob. Change Biol., 19, 1562-1571, doi:10.1111/gcb.12140, 2013.

Ramsay, A. J. and Bawden, A. D.: Effects of sterilization and storage on respiration, nitrogen status and direct counts of soil bacteria using acridine orange, Soil Biol. Biochem., 15, 263-268, doi:10.1016/0038-0717(83)90069-X, 1983.

Sinsabaugh, R. L. and Follstad Shah, J. J.: Ecoenzymatic Stoichiometry and Ecological Theory, Annu. Rev. Ecol Evol. Syst., 43, 313-343, doi:10.1146/annurev-ecolsys-071112124414, 2012.

Sinsabaugh, R. L., Hill, B. H., and Follstad Shah, J. J.: Ecoenzymatic stoichiometry of microbial organic nutrient acquisition in soil and sediment, Nature, 462, 795-798, doi:10.1038/nature08632, 2009.

Stursova, M. and Sinsabaugh, R. L.: Stabilization of oxidative enzymes in desert soil may limit organic matter accumulation, Soil Biol. Biochem., 40, 550-553, doi:10.1016/j.soilbio.2007.09.002, 2008.

Trevors, J. T.: Sterilization and inhibition of microbial activity in soil, J. Microbiol. Meth., 26, 53-59, doi:10.1016/01677012(96)00843-3, 1996.

Tuominen, L., Kairesalo, T., and Hartikainen, H.: Comparison of Methods for Inhibiting Bacterial Activity in Sediment, Appl. Environ. Microb., 60, 3454-3457, 1994.

Turney, C. S. M., Wheeler, D., and Chivas, A. R.: Carbon isotope fractionation in wood during carbonization, Geochim Cosmochim. Ac., 70, 960-964, doi:10.1016/j.gca.2005.10.031, 2006.

Wang, G., Jia, Y., and Li, W.: Effects of environmental and biotic factors on carbon isotopic fractionation during decomposition of soil organic matter, Scientific Report, 5, 1-11, doi:10.1038/srep11043, 2015.

Zyakun, A. M., Kochetkov, V. V., Baskunov, B. P., Zakharchenko, V. N., Peshenko, V. P., Laurinavichius, K. S., Anokhina, T. O., Siunova, T. V., Sizova, O. I., and Boronin, A. M.: Use of glucose and carbon isotope fractionation by microbial cells immobilized on solid-phase surface, Microbiology, 82, 280-289, doi:10.1134/S0026261713030156, 2013. 